\title{
Global value chains and the political economy of WTO disputes
}

\author{
Soo Yeon $\mathrm{Kim}^{1}$ (D) $\cdot$ Gabriele Spilker ${ }^{2}$
}

\begin{abstract}
This paper investigates how the rise of global value chains (GVCs) in international trade affects the political economy of trade disputes. It addresses the gap between the domestic and international politics of trade disputes, which is especially relevant in these times as populist nationalism favors protectionist forces. We advance the argument that firms face institutional disadvantages in opposing protectionist forces at home, as observed in how contesting firms fare in US anti-dumping cases. As a consequence, they have incentive to seek cross-border cooperation with firms along the supply chain to escalate the adoption of anti-dumping measures to WTO disputes. The paper implements a two-stage empirical strategy. First, we examine the political contestation around US anti-dumping cases ongoing in the WTO era that takes place in International Trade Commission (ITC) hearings. We observe that while these cases see significant opposition from firms relying on the imports of intermediate goods, most cases end in favor of petitioners supporting the imposition of anti-dumping duties. In a second step, we quantitatively analyze the effect of intermediate and GVC goods trade in products that are the subjects of anti-dumping cases on the incidence of a formal WTO dispute. The results suggest that the high costs of litigation at the WTO are often prohibitive relative to the volume of trade in question and pose an equally difficult challenge for firms seeking to overturn protectionist measures.
\end{abstract}

Keywords World Trade Organization · Dispute settlement · Multinational firms · Global value chains $\cdot$ Anti-dumping disputes

Soo Yeon Kim

sooyeon.kim@nus.edu.sg

Gabriele Spilker

gabriele.spilker@sbg.ac.at

1 National University of Singapore, Singapore, Singapore

2 University of Salzburg, Salzburg, Austria 


\section{Introduction}

The rise of global value chains (GVCs) reflects the increasing complexity of multinational firms' activities in producing and moving goods across borders. GVCs increasingly feature longer lengths in production, that is, stages of production that are fragmented across more countries and hence require more border crossings that take the form of trade in intermediate goods. The World Trade Organization's (WTO) Global Value Chain Development Report 2017 estimates that trade in intermediate goods contributed over 50\% to growth in global manufacturing trade since the beginning of the 21 st century (39).

GVCs reflect the internationalization of production, in which multinational firms form production networks that locate stages of production in different countries. In doing so, GVCs have affected significant changes in the political economy of trade. In particular, GVCs privilege the role of multinational firms as political actors, both in their home countries and in the host countries in which they invest to locate parts of their production networks. Overall, the growing body of scholarship to date shows that GVCs and trade along the international supply chain have expanded the coalition of interests favoring liberal trade and opposing protectionism (Osgood 2018) and provided for greater protection of multinational firms' property rights (Johns and Wellhausen 2016).

Yet the recent political winds of populist nationalism have strengthened the forces of protectionism. As the introductory essay to this special issue notes, this era of nationalism is very much a phenomenon emerging from the industrialized world (Copelovitch and Pevehouse 2019, this volume). The trade war between the United States and China has already seen the imposition of US $\$ 50$ billion in tariffs, with another US $\$ 200$ billion in abeyance as the world awaits the outcomes of ongoing negotiations. Against this backdrop, this paper examines the challenges facing firms that contest the imposition of protectionist measures in the domestic political arena. The analysis investigates processes and outcomes in anti-dumping cases in the United States. The findings highlight the challenges of opposition in the past that have implications for the present era when the forces of protectionism appear to have the upper hand.

The project is also a broader inquiry into how the internationalization of production has affected the political economy of trade disputes. The analysis begins with an examination of the domestic political arena, in which firms lobby for protection and trade disputes first emerge. The analysis then investigates the factors affecting the transition of trade policy outcomes into the filing of trade disputes at the WTO. The empirical domain is the United States and the cases of anti-dumping investigations undertaken through the International Trade Commission (ITC) and Department of Commerce. While GVC-related issues are likely to affect the political economy of trade in many areas, US anti-dumping cases are particularly appealing as an illustrative area of study, due to the richness of qualitative and quantitative data available on their processes and outcomes. The available records of anti-dumping investigations and hearings provide information on how firms, especially those with links to global value chains, participate in this stage of trade disputes and do so especially as opponents of protectionist measures.

The paper advances two main findings. First, in the domestic political arena of ITC and Department of Commerce investigations and determinations, firms that oppose the 
adoption of anti-dumping measures against imports are largely unsuccessful due to institutionally imposed disadvantages as compared to firms in favor of anti-dumping measures. As anti-dumping cases involve largely determinations of injury to domestic industry as a result of imports, there is little room for opposing viewpoints that seek consideration for how anti-dumping measures may affect other firms that depend on such imports. Second, given the institutional disadvantages to opponents in antidumping cases, the analysis investigates whether such disadvantages in the domestic political arena persist into the international setting where the imposition of antidumping measures may turn into formal trade disputes under the WTO's dispute settlement mechanism. We consider whether anti-dumping cases involving GVCrelated products may incentivize cooperation among firms in both respondent and complainant countries that are connected through their participation in the same supply chain. Yet we also expect the high costs of litigation at the WTO to pose a significant barrier to successful cross-border cooperation. The results indicate, indeed, that these actors face the costly hurdle of filing disputes at the WTO. Few anti-dumping cases turn into WTO disputes to begin with, and even at high levels of trade, the likelihood of filing a dispute for anti-dumping cases involving GVC-goods remains less than 50 percent. This finding is indicative of the collective action problem that besets economic actors considering costly litigation through the WTO's dispute settlement process, where firms have an incentive to free-ride on others that may be willing to bear the costs of WTO litigation.

Our contribution to the existing scholarship is to fill the knowledge gap between the activation of trade disputes at the domestic level and the effect of GVC-related trade on the initiation of WTO disputes. Existing studies show that there is an overall decline, for example, in the petitioning for anti-dumping cases in the United States, driven in large part by intra-firm trade links between potential complainants and respondents (Jensen et al. 2015). Scholarship also shows that for disputes that are litigated at the WTO, the political force of economic actors involved in GVC-trade pushes respondent countries to comply with rulings and do so more quickly (Yildirim et al. 2018). This paper seeks to complete the picture by examining what happens between the trade disputes that do arise, first, on the domestic scene, and, subsequently, how they become WTO disputes. Of particular interest is when and how economic actors involved in GVC-related trade may be politically activated, whether in the domestic arena of ITC investigations or in the escalation to the litigation at the WTO.

Our research is timely in highlighting the importance of domestic politics in shaping trade policy amidst a 'global wave of right-wing populism'. ${ }^{1}$ The sequence of events that led to the Trump Administration's imposition of tariffs on imported steel and aluminum relied on the Department of Commerce's investigation under Section 232 of the 1962 Trade Expansion Act. This legislation confers on the executive the authority both to initiate investigations of imports as threats to national security and to impose tariffs on the resulting recommendations. Much like the cases we examine in the analysis, protectionist measures are often taken in spite of opposition from firms that rely on such imports and are likely to be hurt by the imposition of tariffs. This also paper suggests that the prospects cross-border cooperation between firms involved in

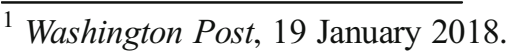


GVCs are likely be deterred by the high costs of litigation in escalating trade conflicts to the WTO.

\section{GVCs, MNCs, and the WTO DSM}

The dispute settlement mechanism (DSM) of the WTO provides its member countries with a mechanism to solve their trade disputes without resorting to unilateral retaliation. Scholars and policy experts alike agree that the WTO DSM is one of the key elements contributing to the process of legalization in the global trading system and thus to the functioning of the international trading system more generally (Busch and Reinhardt 2003; Palmeter 2000; Steger and Hainsworth 1998). Overall, the literature dealing with WTO disputes is plentiful. Studies focus on the design of the WTO dispute body and the comparison to its predecessor under the GATT system (Busch and Reinhardt 2000; Rosendorff 2005; Zangl 2008), on WTO dispute initiation and escalation (Guzman and Simmons 2005; Sattler and Bernauer 2011; Sattler et al. 2014), on the role of developing countries in the WTO (Busch and Reinhardt 2003; Davis and Bermeo 2009; Elsig and Stucki 2012; Francois et al. 2007), or on which countries participate in filing WTO disputes (e.g. Johns and Pelc 2014).

One aspect of the WTO dispute process that has been unattended for a long time, however, is the discrepancy between the actors affected by protectionist measures and those who can do anything about it: '[f]irms do not have legal standing in the [WTO] disputes process. They rely on governments to act as their agents in Geneva' (Lawton and McGuire 2001: 11). ${ }^{2}$ One can thus conceive of states as gatekeepers at the WTO in that they are the only actors able to file disputes (Poletti and De Bièvre 2014). As a consequence, we are confronted with a situation in which governments need to decide which firm interests to adhere to, when and how.

The literature on the WTO DSM has only recently started to evaluate how the interest of firms affects dispute settlement. Following a recent trend in the literature on the political economy of trade policy more generally (e.g. Curran and Eckhardt 2017; Eckhardt and Poletti 2016; Jensen et al. 2015; Kim 2017; Manger 2009), these studies evaluate how the presence of firms that are part of global value chains affects dispute settlement at the WTO. Of particular interest are multinational firms whose production networks are located in different countries to take advantage of lower factor costs and for whom investment protection and legal protection of property rights is especially salient (Kim et al. 2019). Of the literature examining how GVCs affect outcomes of WTO disputes, Yildirim (2018) and Yildirim et al. (2018) show that countries comply much more swiftly with adverse WTO Panel rulings if the dispute affects sectors characterized by the presence of GVCs. The argument underlying this type of research relies on the assumption that firms that are part of GVCs are less likely to lobby for trade protection (Jensen et al. 2015). Rather, due to their production networks spanning across various countries, barriers to trade imply increased costs for these firms and they are therefore more likely to lobby against such protectionist measures.

While this research is a huge step forward in better understanding the process of WTO dispute settlement, they also raise the question of why WTO disputes arise in the

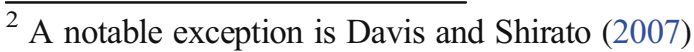


first place. Both Yildirim (2018) and Yildirim et al. (2018) argue that the political influence of GVC interests pushes governments toward compliance with WTO dispute settlement rulings. If this is the case, then how is it that such political influence does not already manifest itself domestically when the trade dispute first emerges? Why don't economic actors, especially multinational firms, engaged in GVC-related trade, exert their political influence to prevent trade disputes from arising in the first place? Why do governments not respond beforehand and concede to the demand of these firms but rather let it escalate to the WTO and through all stages of the WTO DSM just to then swiftly comply? Given that WTO disputes impose high transaction costs (Sattler et al. 2014), findings from this scholarship raise an interesting puzzle: how does the presence and political influence of GVC firms affect how trade disputes arise and progress?

The approach of this paper is to examine two stages of trade disputes that help to fill in the blanks linking the domestic with the international contexts: political contestation in the domestic arena over the adoption of protectionist measures that affect GVCrelated firms and their trade; and how and why such measures become litigated at the WTO. In doing so, we premise our expectations on differences across firms in their incentives for political mobilization.

\subsection{Different firms, different interests}

Recent empirical studies have found some regularities in trade patterns suggesting that firms that export differ from firms producing for their home market, independent of the sector in which they are operating. Exporters tend to be larger in size and are much more productive (Aw et al. 1998; Bernard et al. 2003; Bernard and Jensen 1999; Eaton and Kortum 2002; Eaton et al. 2004). Furthermore, a minority of firms export and those who export typically only serve one or few markets (Eaton et al. 2004). Furthermore, there is the special group of multinationals that are part of global value chains.

Melitz (2003) introduced a theoretical model to account for the observed heterogeneity of firms within industries. In this model, trade liberalization typically benefits those firms that already export and that are most productive whereas it tends to harm non-exporting firms and those that are least productive. The reason for this unequal effect of trade liberalization is that only the most productive firms can offset the increased competition in their home market by higher levels of exports. For the least productive firms, trade liberalization can even imply market exit.

Global or regional value chains act on top of these divisions with respect to trade liberalization. In principle, in each of the three categories of firms - those serving the domestic market only, those also exporting and MNCs - there exist firms that are dependent on inputs from foreign firms and those that are not. Those that depend on such inputs, i.e., those that are part of global or regional value chains, have a strong interest in cheaper inputs, which implies that they want their own country to set no tariff or quotas on such products and to have similar production and safety standards. And each of these different types of firms should have different interests on when and how to rely on the process of WTO DSM, which we lay out in the next section. 


\subsection{Expectations}

To facilitate the clarity of our argument and since our empirical analysis employs data on US anti-dumping cases, expectations about how firms involved in GVC-related trade affect trade dispute outcomes can be illustrated in the area of anti-dumping. Antidumping cases are important for illustrating the theoretical expectations of our paper. The cases clearly identify the supporters - the petitioners - and the opposition, and each set of actors is subject to the institutional rules of the ITC and Department of Commerce in governing the process of anti-dumping investigation and determination. The outcomes are also transparent. We observe the imposition of anti-dumping duties or the termination of a case at some stage of the process. They therefore provide clear empirical grounds for testing the expectations of this paper.

Anti-dumping disputes arise because firms in industry $i$ in State A complain that firms in the same industry of State B sell their products at an unfairly low price thereby causing 'injury' to industry $i$ in State A. As a consequence, State A can decide, once it has established in accordance with the WTO's Anti-Dumping Agreement (ADA) that dumping does indeed take place, to issue anti-dumping duties.

However, in most cases firms in industry $i$ are not the only ones that are likely to be affected by the imports of the respective product. Firms in other industries might rely on the respective product as an input for their production process. For those firms the issuing of anti-dumping duties implies an increase in their prices. As a consequence their final product becomes more expensive thus decreasing their revenue. Hence while anti-dumping duties might be in the interest of some firms they are often costly for other firms within the very same country.

If firms in State A do mobilize politically to initiate the process of AD investigations, there are two potential ways for firms hurt by these prospective AD duties to oppose them or to get rid of them. Either these opposing firms in State A i) lobby the government directly not to impose these anti-dumping duties; or, in the event that the anti-dumping duties have already been imposed, ii) lobby the government of State B for dispute resolution at the WTO. In this latter scenario, firms in State A opposing antidumping measures share interests with the firms in State B that are targeted by these anti-dumping measures. This results in a larger potential coalition that can be mobilized against State A and the anti-dumping measures it has adopted. These common interests would be especially evident for firms that engage in GVC-related trade. Therefore, firms involved anti-dumping cases that are unsuccessful in their opposition and that involve GVC-related goods may have an incentive to seek escalation to the WTO.

At the same time, whether firms (are able to) turn to State B and thus ultimately get access to the WTO DSM should strongly depend on their capacity for collective action and for absorbing the high cost of litigation at the WTO. The quantitative analysis portion of this paper employs the volume of trade in GVC goods as a proxy for the potential for political mobilization. The expectation is that the effect can go in either direction. The costs of litigation at the WTO can pose a significant barrier. Brutger (2014) finds, for example, that the cost of litigation at the WTO can run to one million dollars per year (3). The effect can be positive in the sense that a higher volume of trade in GVC goods reflects greater capacity to absorb the costs of litigation. Alternatively, the effect can also be negative in the sense that more trade in GVC goods also means 
more firms that exacerbate the problem of collective action. The interesting empirical investigation in this regard is which is likely to be a stronger force pushing the likelihood of a WTO dispute in one direction or the other.

\section{Analysis}

We analyze the progression of trade disputes for anti-dumping cases in the United States. Our sample of analysis is largely determined by data availability, both qualitative and quantitative, for the two stages of trade disputes that are of central interest. Transcripts available through the International Trade Commission (ITC) provide qualitative evidence concerning the process of anti-dumping investigations and outcomes. In particular, these transcripts provide evidence of whether firms, especially firms involved in GVC-related trade, engage the ITC's institutional mechanisms to oppose the imposition of anti-dumping measures by the U.S. government. The analysis examines institutions, interests, and outcomes: the rules of engagement for supporters and the opposition in anti-dumping cases; the qualitative arguments that are advanced by the opposition to anti-dumping measures, especially those that are put forward by firms involved in GVC-related trade; and whether or not such opposition is successful in preventing the adoption of anti-dumping duties.

The paper follows with a quantitative analysis of the effect of intermediate/GVC goods trade in products that are the subjects of anti-dumping cases on the incidence of a formal dispute filing at the WTO. The analysis employs a new dataset based on the Temporary Trade Barriers Database (TTBD) compiled by Chad Bown. ${ }^{3}$ The sample of analysis includes anti-dumping disputes that arose in the WTO in the years 1995 to 2015.

\section{Political contestation in US anti-dumping cases}

This section of the paper addresses the question of how WTO dispute cases arise in the first place from domestic-level processes. The analysis focuses on the process of antidumping investigations and determinations in the United States, which has recorded about 1300 anti-dumping cases since the late 1970s. ${ }^{4}$ In describing the process of antidumping investigations and determinations, the discussion highlights the institutional mechanisms for political contestation between petitioning industries, firms in these petitioning industries, and opposing firms.

In the United States, the International Trade Commission (ITC) and the Department of Commerce are charged with enforcing and administering the country's anti-dumping laws. There are largely 3 phases: i) petition; ii) investigation; and iii) review. As detailed below, firms may register their opposition to the imposition of anti-dumping duties during the investigation stage (2nd phase), during a public hearing to determine the outcome of the anti-dumping investigation, and in the review phase (3rd phase) that takes place five years after the actual imposition of anti-dumping duties.

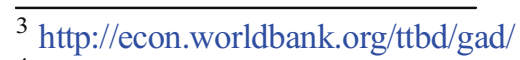

${ }^{4}$ The number of cases is determined from the Temporary Trade Barriers Dataset (Bown 2014)
} 


\subsection{The US anti-dumping investigation process in brief}

Phase 1: Petition The anti-dumping investigation process in the US begins with a petition filed on behalf of an industry, which must provide evidence of material injury due to the 'dumping' of imports by a trade partner.' For a filing to be accepted, domestic supporters of the petition must comprise i) at least 25 percent of total domestic production of the 'like product' and ii) over 50 percent of production of the 'like product' for the portion of the industry either supporting or opposing the petition. ${ }^{6}$ Petitions are required to include information on the quantity and prices of imports that are claimed to be sold at 'less than fair value,' calculated for the three years leading up to the date of filing and including information on firms that 'jumped ship' in favor of cheaper imports.

Phase 2: Investigation The investigation phase consists of 5 stages variously involving the Department of Commerce and the International Trade Commission (ITC). First, investigations are initiated by the Department of Commerce within 20 days of filing of the petition. ${ }^{7}$ It is followed by 2) the preliminary phases of the ITC's and 3) Department of Commerce's investigations, respectively. ${ }^{8}$ In stage 4 , the Department of Commerce finalizes first its investigation, followed by stage 5 in which the ITC concludes its own investigation. ${ }^{9}$ With the concurrence of both investigating bodies on material injury, the Department of Commerce is legally bound, within 7 days, to publish an anti-dumping duty order in the Federal Register.

Phase 3: Review process The Department of Commerce and the ITC are required to undertake a review of the anti-dumping order within 5 years of its implementation. The review is conducted to determine whether revocation of the antidumping duty order would facilitate the resumption of dumping in the products under question. The Department of Commerce publishes a notice in the Federal Register calling for interested parties to participate in the review and to provide information/views on the expected consequences of a revocation. The Department of Commerce is legally bound to revoke the order unless it is determined that i) dumping would resume following revocation and ii) material injury would persist. If there is 'adequate' interest, a full review of the case is conducted, paralleling the procedures of the investigation stage.

\footnotetext{
${ }^{5}$ For an informal guide to the process prepared by staff from the International Trade Commission's Office of Investigations,see the Antidumping and Countervailing Duty Handbook, 14th Ed. (2015).

${ }^{6}$ In cases where this second condition is not fulfilled, the Department of Commerce will conduct a poll to determine the level of support for the petition.

${ }^{7}$ Petitioners are required to file both with the Department of Commerce and the ITC on the same day. The Department of Commerce decides for or against an investigation in response to the petition.

8 The ITC communicates the findings of its preliminary investigation to the Department of Commerce within 45 days, and the Department of Commerce completes this stage within 115 days after that of the ITC.

${ }^{9}$ The Department of Commerce makes its final determination within 235 days of the filing of the petition. Within 45 days after the final determination of the Department of Commerce, the ITC also makes its final determination.
} 


\subsection{Registering opposition: Evidence from public hearings of anti-dumping cases}

Institutional mechanisms for opposition are provided in the Department of Commerce and ITC's anti-dumping investigation and determination procedures. Opportunities for contesting the petition for anti-dumping duties are concentrated in phase 2: the preliminary and final determinations of the two investigative bodies; and in phase 3 , in the event of a full investigation concerning the revocation of an existing antidumping measure.

As part of anti-dumping investigations, non-petitioners may participate in the preliminary investigation of the ITC; to do so, the respective party files an 'entry of appearance' with the ITC Secretary. If the Secretary deems this party to have a 'proper reason' for joining the investigative process, the non-petitioner is included in the 'public service list' document. ${ }^{10}$ What is interesting to note is that the investigations involve questionnaires that are required to be filled out by importers, especially those importing from the countries under investigation. That is, the investigations do involve querying those that import goods from the prospective target country, that is, domestic firms that are likely opponents to anti-dumping measures.

Opposition to petitions for anti-dumping investigations are most prominent in the preliminary and final stages of the ITC investigation, when a public conference is held to determine whether an anti-dumping order should be passed. In this public hearing, parties both in support of and in opposition to the petition are given time to make opening statements (five minutes) and support their respective positions with testimonies from witnesses (one hour). Cross-examination is not permitted, but each side is given ten minutes after the presentation for rebuttal and summary. In the review stage for the five-year mark of anti-dumping measures, a similar hearing also takes place in the event of a full review. Again, importers are required to fill out mandatory questionnaires on the impact of the existing anti-dumping measure. At the hearing, parties supporting and opposing firms - are given the opportunity to present their positions.

The ITC's online archive provides records of public hearings for cases since 2002/2003. While Chad Bown's data on US anti-dumping cases records well over 1300 investigations that have been initiated since the 1970s, records on the ITC website show approximately 300 unique cases since 2002/2003, that is, cases that can be uniquely identified by the original petition and investigation and including all subsequent five-year reviews, if any. As of this writing, 159 cases are classified as 'completed' or 'final,' that is, they are the most current cases for which ITC has completed investigations of injury or made final determinations on anti-dumping measures. The remaining cases are those that have expired or have passed through repeated reviews and are still in effect.

Our research into these records shows that a significant majority of anti-dumping petitions are contested, with firms going on record in the public hearings to oppose the anti-dumping petition. Records show that of the 157 cases for which records are available, opposition is recorded in 136 cases, about $87 \%$. The records of public hearings also invariably identify the firms that are in opposition to the anti-dumping petition. In one of the most recent cases concerning the petition against imports of

\footnotetext{
${ }^{10}$ Requests for inclusion must be filed with the ITC Secretary within 7 days of the ITC's announcement in the Federal Register of its intention to investigate.
} 
carbon, alloy steel and cut-to-length plate from Austria, Belgium, Brazil, China, France, Germany, Italy, Japan, Korea, South Africa, Taiwan and Turkey, the opposing firms included importers Dillinger America, Berg Steel Pipe Corporation, TheKnifeSource, and a business association - the National Tooling and Machining Association. ${ }^{11,12}$

Some notable arguments for opposing the anti-dumping measure included that of the representative of U.S. importer Dillinger America, who pointed out the need for imports as domestic producers could not adequately meet demand. The President of the U.S. knife steel manufacturing enterprise TheKnifeSource opposed the antidumping measure on the grounds that domestic producers have 'shown no interest' in producing the special type of knife steel bars that his industry requires. In addition, a representative of the National Tooling and Machining Association argued that grades of tool steel from US producers did not meet their own production requirements, which necessitated the turn to better quality imports - at a much lower price.

The above case refers to some of the most frequent rationales for opposing the imposition of anti-dumping measures. First, many cases refer to the shortfall in supply of the product in question. The lack of adequate supply can be expressed in terms of sheer volume but also products that satisfy a particular set of standards. Products conforming to particular standards are likely to be in demand among domestic importers that employ them as intermediate inputs for products that are then exported. Second, opposition arguments also point to the problematic quality of the domestic product. This may be expressed in the general terms of overall quality, but often in terms of meeting certain product quality standards that are in force in particular industries, such as those referred to in the arguments of the National Tooling and Machine Association in the case above.

Third, some mention is made of supply chain considerations in opposing the imposition of anti-dumping measures. In the case of imports of silicon metal from Russia, whose investigation took place between 20 September 2002 and 19 March 2003, the petition was filed by the United Steel Workers of America, US producer Globe Metallurgical, the International Union of Electronic, Electrical, Salaried, Machine and Furniture Workers, and the Paper, Allied Industrial Chemical and Energy Workers international Union. On the opposing side in the public hearings was US importer G.E. Silicones (now named Momentive Performance Materials) as well as the Russian producer Brastk Aluminum Smelter. The representative from GE Silicones cited the firm's desire to 'fully participate' in the Russian economy and hence it was 'important to the business to keep Russia as a supplier to provide geographic diversity in the supply chain as required by prudence and by the (firm's) corporate policy'. ${ }^{13}$

\subsection{Outcomes of US anti-dumping investigations}

Despite the extensive opposition registered during the hearings, anti-dumping investigations overwhelmingly find in favor of domestic industries. In 129 cases, about 82\%,

\footnotetext{
${ }^{11}$ This new case is at this point 'complete' and the records available as the ITC has only recently made its first determination that imports have caused 'material injury.'

${ }^{12}$ Investigation Nos: 701-TA-560-561 and 731-TA-1317-1328, available on the ITC website.

${ }^{13}$ Investigation No: 731-TA-991. Transcript can be found on the ITC website.
} 
the ITC found evidence of 'material injury' in spite of opposing arguments, which provides the legal basis on which the Department of commerce then imposes antidumping duties. Thus firms that oppose the imposition of anti-dumping measures against countries from which they import see few successes. The lack of success of opposition firms can be ascribed to an institutional bias in ITC/Department of Commerce investigations and determinations. It should be noted that the mandate of the ITC and the Department of Commerce is to investigate whether there has been antidumping activities by foreign firms such that they have caused serious and consistent injury to domestic firms. The process of anti-dumping investigations and hearings emphasizes the determination of injury and the dumping margin for imposing duties on offending firms. ${ }^{14}$ While opposing interests have the right of expression at various points in the hearing, it is not clear just how much weight they have in affecting outcomes. The rationales advanced for not imposing anti-dumping duties may well be irrelevant to establishing whether and to what extent petitioning firms and their respective industries have been injured.

\section{From ITC to WTO}

In this section, we conduct a quantitative analysis of the likelihood of US anti-dumping (AD) cases turning into WTO dispute settlement cases. To do so we created a new dataset based on the Temporary Trade Barriers Database (TTBD) compiled by Chad Bown. ${ }^{15}$ Since our interest lies in estimating which US AD disputes escalate into WTO disputes, we restrict our analysis to anti-dumping cases that arose in the WTO period starting in 1995 until 2015.

In order to determine whether a specific dispute involves GVC trade or not, we needed to determine the specific products under investigation in each case. Overall the original TTBD data contain 1306 AD cases. We were able to identify for 581 antidumping cases the particular products involved and most of these disputes involve more than one product. Hence our unit of analysis is the AD dispute product combination. This results in a total of 12,337 cases of which a majority is at the HS10 level $(11,019)$ and a minority at the HS8 $(1,115)$ and HS6 level $(203)$.

Out of the 581 anti-dumping cases 30 turned into WTO disputes. ${ }^{16}$ Table 1 provides an overview of all WTO disputes included in our analysis. The first dispute arose in 1996 based on a complaint by Mexico and the latest dispute included in our analysis is from 2015 filed by Indonesia.

The dependent variable in our analysis is simply whether a WTO dispute arose out of the respective AD dispute. Thus, the variable WTO dispute takes the value of 1 if a given US anti-dumping case becomes a WTO dispute and 0 otherwise. We follow the literature on WTO initiation (Guzman and Simmons 2005; Sattler and Bernauer 2011; Sattler et al. 2014) and treat the request for consultation as the trigger of a WTO

\footnotetext{
${ }^{14}$ A flowchart of the US anti-dumping process can be found here: . Accessed October 31, 2018.

${ }^{15} \mathrm{http} / /$ econ.worldbank.org/ttbd/gad/

${ }^{16}$ The overall number of WTO disputes in which the US acted as respondent in the WTO period until 2015 was 49.
} 
Table 1 Overview of WTO disputes

DSU Name of dispute number
Complainant Year of consultation

DS-049 Anti-Dumping Investigation Regarding Imports of Fresh or Chilled Tomatoes

DS-179 Anti-Dumping measures on Stainless Steel Plate in Coils and Stainless Steel Sheet and Strip

DS-184 Anti-Dumping Measures on Certain Hot-Rolled Steel Products

DS-206 Anti-Dumping and Countervailing Measures on Steel Plate

DS-247 Provisional Anti-Dumping Measure on Imports of Certain Softwood Lumber

DS-264 Final Dumping Determination on Softwood Lumber

DS-277 Investigation of the International Trade Commission in Softwood Lumber

DS-294 Laws, Regulations and Methodology for Calculating Dumping Margins (Zeroing)

DS-310 Determination of the International Trade Commission in Hard Red Spring Wheat

DS-322 Measures Relating to Zeroing and Sunset Reviews

DS-325 Anti-Dumping Determinations regarding Stainless Steel

DS-335 Anti-Dumping Measure on Shrimp

DS-343 Measures Relating to Shrimp

DS-344 Final Anti-Dumping Measures on Stainless Steel

DS-345 Customs Bond Directive for Merchandise Subject to Anti-Dumping/Countervailing Duties

DS-350 Continued Existence and Application of Zeroing Methodology

DS-368 Preliminary Anti-Dumping and Countervailing Duty Determinations on Coated Free Sheet Paper

DS-379 Definitive Anti-Dumping and Countervailing Duties on Certain Products

DS-382 Anti-Dumping Administrative Reviews and Other Measures Related to Imports of Certain Orange Juice

DS-383 Anti-Dumping Measures on Polyethylene Retail Carrier Bags

DS-402 Use of Zeroing in Anti-Dumping Measures Involving Products

DS-404 Anti-dumping Measures on Certain Shrimp

DS-422 Anti-Dumping Measures on Shrimp and Diamond Sawblades

DS-424 Anti-Dumping Measures on Imports of Stainless Steel Sheet and Strip in Coils

DS-429 Anti-Dumping Measures on Certain Shrimp

DS-449 Countervailing and Anti-dumping Measures on Certain Products

DS-464 Anti-Dumping and Countervailing Measures on Large Residential Washers

DS-471 Certain Methodologies and their Application to Anti-Dumping Proceedings Involving

DS-488 Anti-Dumping Measures on Certain Oil Country Tubular Goods

DS-491 Anti-Dumping and Countervailing Measures on Certain Coated Paper

\begin{tabular}{|c|c|}
\hline Mexico & 1996 \\
\hline Korea & 1999 \\
\hline Japan & 1999 \\
\hline India & 2000 \\
\hline Canada & 2002 \\
\hline Canada & 2002 \\
\hline Canada & 2002 \\
\hline EU & 2003 \\
\hline Canada & 2004 \\
\hline Japan & 2004 \\
\hline Mexico & 2005 \\
\hline Ecuador & 2004 \\
\hline Thailand & 2006 \\
\hline Mexico & 2006 \\
\hline India & 2006 \\
\hline EU & 2006 \\
\hline China & 2007 \\
\hline China & 2008 \\
\hline Brazil & 2008 \\
\hline Thailand & 2008 \\
\hline South Korea & 2009 \\
\hline Vietnam & 2010 \\
\hline China & 2010 \\
\hline EU & 2011 \\
\hline Vietnam & 2012 \\
\hline China & 2012 \\
\hline South Korea & 2013 \\
\hline China & 2013 \\
\hline South Korea & 2014 \\
\hline Indonesia & 2015 \\
\hline
\end{tabular}


dispute. Yet we also check the robustness of our results by using the establishment of a panel $(1=$ yes, $0=$ no $)$ as a second dependent variable.

To measure the presence of GVC trade - our independent variable of interest - we rely on two approaches. First, we use the percentage of intra-firm trade in total trade for the respective product between the US and the complainant country. The data come from the NAICS Related Party Database of the US Census Bureau. ${ }^{17}$ This particular measure enables us to distinguish explicitly between vertical and arm's length trade as in other studies of the impact of GVCs on trade liberalization (Baccini et al. 2018). While this measure corresponds as closely as possible to our theoretical quantity of interest, GVC trade, data are only available starting in 2002. Hence we rely on two additional variables to be able to analyze the whole period of investigation - intermediate good and GVC good. In particular, the variable intermediate good measures whether a product is an intermediate good (1) or not (0). To identify the products that are part of global value chains, we matched the product codes with those on the UNCTAD Standard Product Group List pertaining to intermediate goods. ${ }^{18}$ Intermediate goods are those that are used to produce final goods or products, and thus placement on this list indicates strongly that the particular product at the center of an anti-dumping case is also part of the trade along global value chains. 11,646 of the products in our dataset are intermediate products. The variable GVC good is also a dummy variable and taken from the World Integrated Trade Solution (WITS). ${ }^{19}$ WITS provides HS codes for both final and intermediate goods that are part of GVCs. 1,826 products in our dataset correspond to this classification of GVC product. We use both variables in different models and interact them with the share of bilateral trade in the respective product between the US and the complainant country to be able to measure the importance of trade in the respective product category.

In addition to our variable(s) measuring the presence of GVC trade, we include standard control variables typically included in models of WTO dispute initiation. Since the complainant in our dataset is all the time the US, respondent characteristics are fixed. Hence we only include control variables for the complainant country in our models. In particular, these are GDP per capita as a measure of legal capacity (Busch and Reinhardt 2003) and total GDP to account for the market size of the complainant (Bown 2010). Data for both variables are taken from the World Development Indicators. ${ }^{20}$ The political system of the complainant country as proxied by the Polity IV index is also included. ${ }^{21}$ Finally, we control for overall bilateral trade between the US and the complainant country from which we have subtracted the product specific trade. This variable is included to account for the gravitational logic that more trade implies more (potential) disputes (Sattler and Bernauer 2011). The data were obtained from the UN ComTrade Database. ${ }^{22}$ To account for the fact that different presidents might have different stances towards issuing anti-dumping tariffs we also include two further dummy variables, Bush and Obama, in the model. Finally, since many products

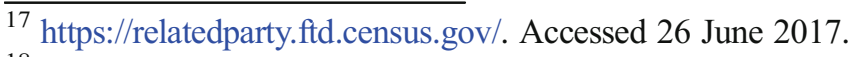

$18 \mathrm{http}: / /$ wits.worldbank.org/referencedata.html

$19 \mathrm{https}: / /$ wits.worldbank.org/referencedata.html

${ }^{20} \mathrm{https}$ //data.worldbank.org/data-catalog/world-development-indicators

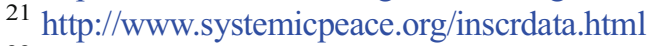

22 https://comtrade.un.org/
} 
included in our analysis belong to the same industry and lobbying mostly happens at the industry level we also include industry, i.e. HS1 level, fixed effects in our models.

\subsection{Results}

Table 2 shows the results of a logistic regression estimating the likelihood of WTO dispute initiation. All models are estimated with robust standard errors clustered at the country level to account for the fact that several countries issue more than one dispute against the US. The relevant coefficient for our theoretical argument is the interaction between GVC or intermediate product and trade in the respective product, which is displayed in the third and fifth rows, respectively. While GVC good is negative and statistically significant, the interaction effect intermediate*trade has a positive sign but does not reach standard levels of significance. This does not change if we look at the establishment of a panel instead, see Model 3 in Table 2. If we consider the variable intermediate good instead, see Models 2 and 4 in Table 2, we can see that both variables are actually insignificant.

To facilitate interpretation of the interaction effect, Figure 1 displays the coefficient on GVC Good at various levels of (ln) Imports of Product based on Model 1 in Table 2. The results illustrate that at low levels of trade in GVC goods the likelihood of the respective AD dispute turning into a WTO dispute is lower than for non-GVC goods.

While the estimate of the coefficient on GVC Good is rather imprecise at low levels of trade (In) Imports of Product ), where the confidence intervals are the most narrow, in the middle values, the effect of GVC Good is still negative. At higher levels of trade the effect becomes positive but the estimates are not statistically significant. The results suggest that GVC-related trade is not more likely than trade in non-GVC goods to result in WTO disputes. ${ }^{23}$

Figure 1 illustrates very well the barriers to litigation at the WTO for firms that are considering lobbying their governments for this option. As noted above, Brutger (2014 finds that WTO disputes cost several million dollars to file; one estimate put the cost at about one million dollars per year (3). The median value in the distribution of $(\log )$ Imports of Product is about 14.3, which translates to just over $\$ 1.6$ million. That is, an 'average' anti-dumping case involves about $\$ 1.6$ million in trade in the product at the center of the anti-dumping case. This amount is equivalent to cost of legal fees for approximately one and a half years of a WTO dispute. Given that the average duration of a WTO dispute is three years including the Panel stage, appeal, and implementation, the value of trade involved in the anti-dumping cases is well below the legal costs of taking the case to the WTO. While the figure shows that estimates are on an upward trend as trade volumes rise, they remain negative for most part. Though the estimate does turn positive at the highest levels of trade - over $\$ 5$ million - there are too few cases to provide accurate estimates of the effect. Thus while anti-dumping disputes involving GVC goods may create common interests across borders, the costliness of litigation does not distinguish GVC-related trade from other forms of trade.

\footnotetext{
${ }^{23}$ The same results hold for the interaction effect between Intermediate Good and (log) Imports of Product. It shows that Intermediate Good is insignificant over the entire range of (log) Imports of Product. The results are available on request.
} 
Table 2 Likelihood of WTO dispute Consultations

\begin{tabular}{|c|c|c|c|c|}
\hline & \multicolumn{2}{|c|}{ Consultations } & \multicolumn{2}{|l|}{ Panel } \\
\hline & (1) & (2) & (3) & (4) \\
\hline \multirow[t]{2}{*}{ (ln) Imports of Product } & 0.004 & 0.11 & 0.01 & 0.05 \\
\hline & $(0.035)$ & $(0.099)$ & $(0.036)$ & $(0.091)$ \\
\hline \multirow[t]{2}{*}{ GVC Good } & $-3.65 * *$ & & $-3.33 *$ & \\
\hline & (1.824) & & (1.878) & \\
\hline \multirow[t]{2}{*}{$G V C^{*}(\ln )$ Imports } & 0.17 & & 0.15 & \\
\hline & $(0.107)$ & & $(0.110)$ & \\
\hline \multirow[t]{2}{*}{ Intermediate Good } & & 1.86 & & 0.54 \\
\hline & & $(1.862)$ & & $(1.672)$ \\
\hline \multirow[t]{2}{*}{ Intermediate*(In) Imports } & & -0.10 & & -0.03 \\
\hline & & $(0.119)$ & & $(0.110)$ \\
\hline \multirow[t]{2}{*}{ Polity } & $-0.12 * * *$ & $-0.12 * * *$ & $-0.13 * * *$ & $-0.13 * * *$ \\
\hline & $(0.035)$ & $(0.036)$ & $(0.034)$ & $(0.035)$ \\
\hline \multirow[t]{2}{*}{ (ln) $G D P$} & $0.55^{* *}$ & $0.55 * *$ & $0.51 * * *$ & $0.51 * * *$ \\
\hline & $(0.216)$ & $(0.215)$ & $(0.194)$ & $(0.193)$ \\
\hline \multirow[t]{2}{*}{ (ln) GDP per capita } & 0.23 & 0.22 & 0.27 & 0.26 \\
\hline & $(0.225)$ & $(0.222)$ & $(0.219)$ & $(0.217)$ \\
\hline \multirow[t]{2}{*}{ Bush } & $-2.07 * * *$ & $-2.06 * * *$ & $-1.73 * * *$ & $-1.72 * * *$ \\
\hline & $(0.403)$ & $(0.407)$ & $(0.308)$ & $(0.312)$ \\
\hline \multirow[t]{2}{*}{ Obama } & $-2.43 * * *$ & $-2.40 * * *$ & $-1.83 * * *$ & $-1.81 * * *$ \\
\hline & $(0.820)$ & $(0.821)$ & $(0.660)$ & $(0.662)$ \\
\hline \multirow[t]{2}{*}{ (In) Bilateral Trade } & $0.53 *$ & $0.53 *$ & 0.20 & 0.20 \\
\hline & $(0.306)$ & $(0.308)$ & $(0.225)$ & $(0.222)$ \\
\hline \multirow[t]{2}{*}{ Constant } & $-14.32 * *$ & $-16.52 * * *$ & $-14.98 * * *$ & $-15.93 * * *$ \\
\hline & $(6.436)$ & $(6.131)$ & $(5.760)$ & $(5.652)$ \\
\hline Industry fixed effects & yes & yes & yes & yes \\
\hline Observations & 6314 & 6314 & 6314 & 6314 \\
\hline Pseudo $\mathrm{R}^{2}$ & 0.30 & 0.30 & 0.28 & 0.27 \\
\hline
\end{tabular}

Robust standard errors in parentheses

$* * * \mathrm{p}<0.01, * * \mathrm{p}<0.05, * \mathrm{p}<0.1$

With regard to the control variables, we observe that countries with larger markets and that trade more with the US are more likely to see AD disputes turn into WTO disputes. More democratic countries are, on the other hand, less likely to escalate their AD disputes to the WTO. GDP pc, finally, does not seem to matter much. If we look at the countries that actually file AD WTO disputes against the US and are included in our sample (see Table 1), we observe that the list includes countries with strongly varying GDP per capita levels from Indonesia and Vietnam to the EU and Canada.

Turning to our second measure of GVC trade, Table 3 shows the results if we use Percent of intra-firm trade instead of the interaction between intermediate good and 


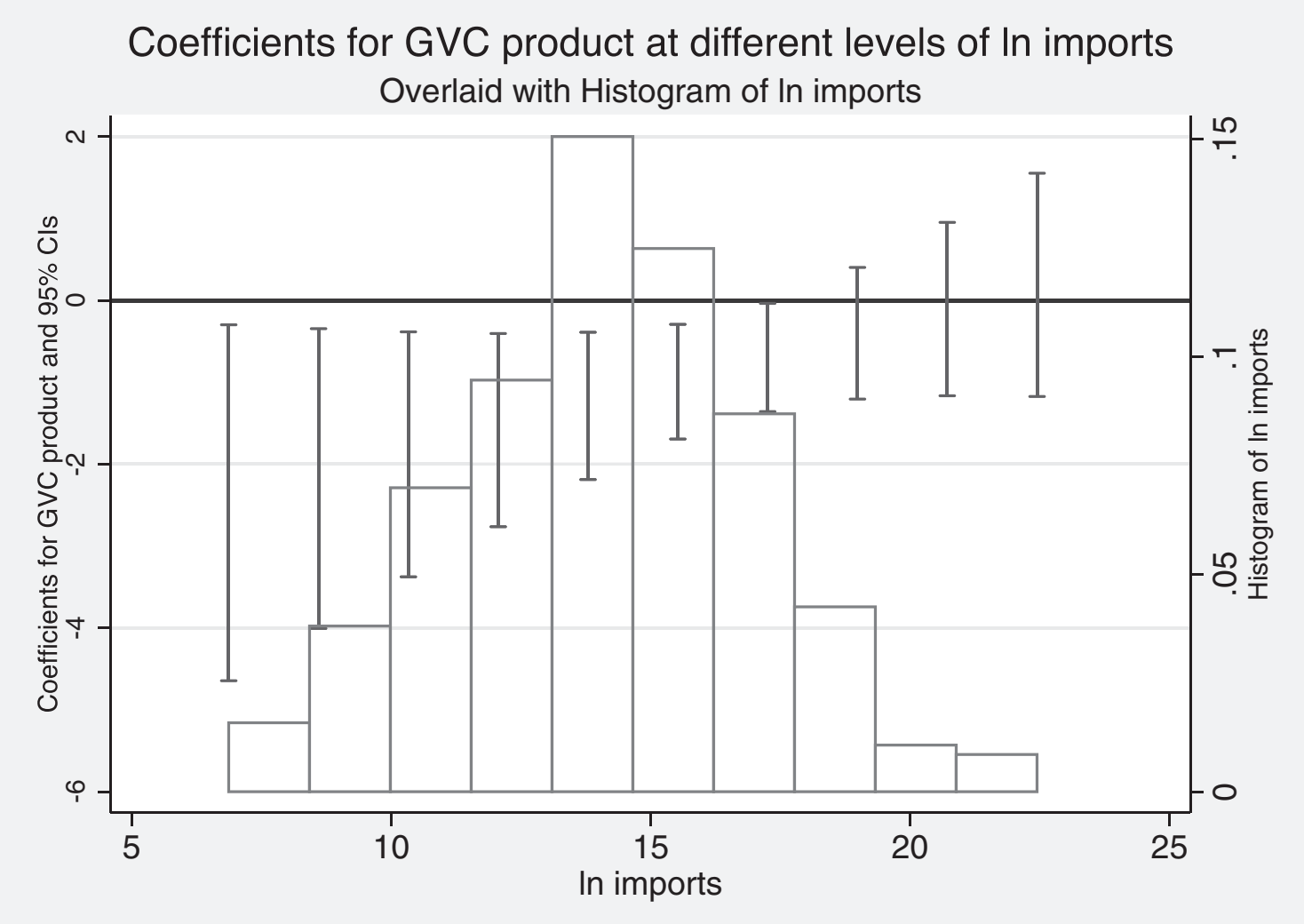

Fig. 1 Interaction effect between GVC Good and (ln) Imports of Product

product-specific trade. Since this measure is only available from 2002 onwards the number of observations is drastically reduced. Yet again the findings are similar as in Table 2 above: Disputes involving higher levels of intra-firm trade are no more likely to see a WTO dispute than AD disputes involving other types of products.

To further illustrate the findings from our analyses, Table 4 shows the predicted probabilities of observing a WTO dispute at various constellations of our variables. In particular, the first two rows show the predicted probability of observing a WTO dispute for a GVC GOOD once if imports of this respective product are at the minimum and once if trade is at the maximum level with the interaction effect taking on the corresponding value. $^{24}$ Two things become apparent: First, in cases where there is little import of a GVC product a WTO dispute is extremely unlikely. Second, although a WTO dispute becomes much more likely at high import levels, in fact the likelihood of a dispute given this particular set of covariates becomes almost $40 \%$, the difference between $\mathrm{AD}$ disputes involving GVC goods and those that do not is statistically insignificant. Hence both AD disputes with and without GVC involvement have a similar likelihood of resulting in a WTO dispute at high import levels. Finally, the last two rows in Table 4 illustrate the predicted probabilities of observing a WTO dispute once at the minimum value of intrafirm trade and once at the maximum level. We can observe that while the likelihood of a

\footnotetext{
${ }^{24}$ All other continuous variables are kept at their mean value while Obama is set to zero, Bush is set to one and the industry fixed effects are all set to zero such that the predicted probabilities illustrate a metal product.
} 
Table 3 Likelihood of WTO dispute - logistic regression

\begin{tabular}{|c|c|c|}
\hline & $\begin{array}{l}\text { (1) } \\
\text { Consultation }\end{array}$ & $\begin{array}{l}(2) \\
\text { Panel }\end{array}$ \\
\hline Percent of Intra-firm Trade & $\begin{array}{l}0.01 \\
(0.010)\end{array}$ & $\begin{array}{l}0.01 \\
(0.011)\end{array}$ \\
\hline (ln) Imports of Product & $\begin{array}{l}0.05 * * \\
(0.025)\end{array}$ & $\begin{array}{l}0.06 * * * \\
(0.024)\end{array}$ \\
\hline Polity & $\begin{array}{l}-0.15 * * * \\
(0.050)\end{array}$ & $\begin{array}{l}-0.16 * * * \\
(0.053)\end{array}$ \\
\hline (ln) GDP & $\begin{array}{l}0.90 * * * \\
(0.265)\end{array}$ & $\begin{array}{l}0.85^{* * *} \\
(0.262)\end{array}$ \\
\hline (ln) GDP per capita & $\begin{array}{l}-0.44 \\
(0.329)\end{array}$ & $\begin{array}{l}-0.57 \\
(0.353)\end{array}$ \\
\hline Bush & $\begin{array}{l}-0.81 * * * \\
(0.242)\end{array}$ & $\begin{array}{l}-1.12 * * * \\
(0.231)\end{array}$ \\
\hline (ln) Bilateral Trade & $\begin{array}{l}0.25 \\
(0.522)\end{array}$ & $\begin{array}{l}0.09 \\
(0.487)\end{array}$ \\
\hline Constant & $\begin{array}{l}-22.25 * * * \\
(5.897)\end{array}$ & $\begin{array}{l}-20.16^{* * * *} \\
(6.119)\end{array}$ \\
\hline Industry fixed effects & yes & yes \\
\hline Observations & 3029 & 3029 \\
\hline Pseudo $\mathrm{R}^{2}$ & 0.49 & 0.49 \\
\hline
\end{tabular}

Robust standard errors in parentheses.

$* * * p<0.01, * * p<0.05, * p<0.1$

Table 4 Predicted probabilities of observing WTO dispute

Probability of WTO dispute

GVC GOOD = 1

0.06

(ln) Imports of Product $=$ minimum

$(0.00-0.32)$

GVC GOOD = 1

0.36

(ln) Imports of Product $=$ maximum

(0.10-0.71)

GVC GOOD $=0$

0.32

(ln) Imports of Product $=$ minimum

(0.15-0.53)

GVC GOOD $=0$

0.33

(ln) Imports of Product $=$ maximum

(0.16-0.55)

Percent of Intra-firm Trade $=$ minimum

0.20

(0.12-0.31)

Percent of Intra-firm Trade = maximum

0.36

(0.04-0.82)

95\% Confidence Intervals in parentheses 
Table 5 Likelihood of WTO dispute - logistic regression - reduced dataset

\begin{tabular}{|c|c|c|c|c|}
\hline & \multicolumn{2}{|c|}{ Consultations } & \multicolumn{2}{|l|}{ Panel } \\
\hline & (1) & (2) & (3) & (4) \\
\hline \multirow[t]{2}{*}{ (ln) Imports of Product } & $0.48 * * *$ & 0.57 & $0.47 * * *$ & 0.48 \\
\hline & $(0.084)$ & $(0.383)$ & $(0.080)$ & $(0.322)$ \\
\hline \multirow[t]{2}{*}{ GVC Good } & -1.61 & & -0.27 & \\
\hline & $(4.077)$ & & $(3.744)$ & \\
\hline \multirow[t]{2}{*}{ GVC*(ln) Imports } & 0.02 & & -0.05 & \\
\hline & $(0.169)$ & & $(0.154)$ & \\
\hline \multirow[t]{2}{*}{ Intermediate Good } & & 2.96 & & 1.33 \\
\hline & & $(6.545)$ & & $(5.478)$ \\
\hline \multirow[t]{2}{*}{ Intermediate*(ln) Imports } & & -0.18 & & -0.08 \\
\hline & & $(0.375)$ & & $(0.316)$ \\
\hline \multirow[t]{2}{*}{ Polity } & $-0.05^{* *}$ & $-0.05 * *$ & $-0.05^{* *}$ & $-0.05^{* *}$ \\
\hline & $(0.023)$ & $(0.022)$ & $(0.021)$ & $(0.022)$ \\
\hline \multirow[t]{2}{*}{ (ln) GDP } & $0.29 *$ & $0.29 *$ & $0.30 *$ & $0.30 * *$ \\
\hline & $(0.156)$ & $(0.153)$ & $(0.154)$ & $(0.152)$ \\
\hline \multirow[t]{2}{*}{ (ln) GDP per capita } & 0.09 & 0.09 & 0.07 & 0.07 \\
\hline & $(0.153)$ & $(0.147)$ & $(0.153)$ & $(0.147)$ \\
\hline \multirow[t]{2}{*}{ Bush } & 0.38 & 0.32 & 0.44 & 0.41 \\
\hline & $(0.348)$ & $(0.390)$ & $(0.360)$ & $(0.389)$ \\
\hline \multirow[t]{2}{*}{ Obama } & -0.49 & -0.45 & -0.30 & -0.28 \\
\hline & $(0.674)$ & $(0.637)$ & $(0.650)$ & $(0.620)$ \\
\hline \multirow[t]{2}{*}{ (ln) Bilateral Trade } & -0.11 & -0.05 & -0.18 & -0.12 \\
\hline & $(0.193)$ & $(0.168)$ & $(0.205)$ & $(0.185)$ \\
\hline \multirow[t]{2}{*}{ Constant } & $-18.18 * * *$ & $-19.81 * * *$ & $-19.69 * * *$ & $-19.49 * * *$ \\
\hline & $(4.629)$ & $(6.702)$ & $(4.378)$ & $(6.098)$ \\
\hline Industry fixed effects & yes & yes & yes & yes \\
\hline Observations & 524 & 524 & 524 & 524 \\
\hline Pseudo $\mathrm{R}^{2}$ & 0.18 & 0.17 & 0.18 & 0.17 \\
\hline
\end{tabular}

Robust standard errors in parentheses

$* * * \mathrm{p}<0.01, * * \mathrm{p}<0.05, * \mathrm{p}<0.1$

WTO dispute increases by 16 percentage points if we move from the minimum to the maximum level, the difference is still not statistically significant.

In a next step, we provide the same analysis as above yet with a collapsed version of our data. In particular, we keep only one observation per $\mathrm{AD}$ dispute and aggregate the product trade over the entire range of products involved in each AD dispute. This estimation strategy has the advantage that we do not create several very similar observations by including all product categories for all AD disputes. While these products vary in their trade level they do not vary for all other covariates in our model, such as respondent and dispute characteristics. The results as displayed in Table 5 provide, however, for the same conclusion as the results based on the extended dataset. 
Table 6 Likelihood of WTO dispute - logistic regression - reduced dataset

\begin{tabular}{lll}
\hline & $(1)$ & $(2)$ \\
& Consultations & Panel \\
\hline Percent of Intra-firm Trade & -0.01 & -0.01 \\
& $(0.011)$ & $(0.011)$ \\
(ln) Imports of Product & $0.31^{* * *}$ & $0.30^{* * *}$ \\
& $(0.063)$ & $(0.061)$ \\
Polity & $-0.06^{*}$ & $-0.07^{* *}$ \\
& $(0.034)$ & $(0.033)$ \\
(ln) GDP & 0.28 & 0.30 \\
& $(0.179)$ & $(0.177)$ \\
(ln) GDP per capita & 0.09 & 0.03 \\
& $(0.225)$ & $(0.237)$ \\
Bush & 0.09 & -0.03 \\
& $(0.189)$ & $(0.198)$ \\
(ln) Bilateral Trade & -0.22 & -0.32 \\
& $(0.277)$ & $(0.282)$ \\
Constant & $-15.04 * * *$ & $-15.80^{* * * *}$ \\
Industry fixed effects & $(5.408)$ & $(5.318)$ \\
Observations & yes & yes \\
Pseudo R ${ }^{2}$ & 261 & 261 \\
\hline
\end{tabular}

Robust standard errors in parentheses.

$* * * \mathrm{p}<0.01, * * \mathrm{p}<0.05, * \mathrm{p}<0.1$

AD disputes involving GVC products are no more likely to result in WTO disputes than $\mathrm{AD}$ disputes involving non-GVC products.

Finally, Table 6 shows the results using percent of intra-firm trade as a measure of GVC trade. Again the results do not differ substantially from those based on the extended version of the dataset. Intra-firm trade is again not significantly related to dispute initiation and hence we cannot conclude that those AD disputes involving higher levels of intra-firm trade are more likely to result in a WTO dispute.

Concerning the control variables, the models presented in Tables 5 and 6 differ only in terms of significance levels from the results based on the extended dataset. Yet as the number of observations is highly reduced this was to be expected. The one exception is the coefficient on bilateral trade, which in Tables 5 and 6 is negatively signed yet statistically insignificant. Overall, we can conclude from these models that countries with larger market size are more likely to initiate a dispute against the US at the WTO and they are more likely to do so if they have a high level of legal capacity measured by $G D P$ pc. This is again illustrative of the high costs of filing WTO disputes as illustrated by Brutger (2014). Countries that seem most likely to overcome these costs are those with high levels of GDP per capita and those for whom the dispute is most likely worthwhile in terms of trade levels and market size. 


\section{Conclusion}

As a study contributing to this special issue on 'International Organizations in a New Era of Populist Nationalism,' this paper examines the major hurdles that make political mobilization of pro-trade groups difficult, whether opposing anti-dumping measures at home or seeking formal dispute settlement at the WTO. The pro-trade forces such as those that oppose the imposition of anti-dumping duties on our major trading partners are especially salient as they comprise an important part of the political coalition of forces opposing the economic nationalism of these times. This paper analyzes when and how they might matter in the course of domestic politics in advancing their position and contesting the rise of protectionism.

Our research question addresses a puzzle motivated by existing scholarship on the incidence of WTO disputes: why are GVC-related firms successful at ensuring compliance with WTO dispute settlement rulings but not so in preventing such disputes in the first place? To address this question, the analysis examined, first, the process of anti-dumping investigations, hearings, and outcomes in the United States; and second, the conditions under which these anti-dumping cases escalate to the WTO for dispute settlement.

This paper reports two main findings. First, the analysis shows that for anti-dumping cases in the United States, petitioning firms or industry actors seeking the imposition of anti-dumping measures have an institutional advantage that makes the opposition much less likely to be successful. The ITC/Department of Commerce's investigations emphasize the determination of injury to domestic producers due to imports of particular products; it is unclear to what extent they are charged with considering the benefits or the possible costs of anti-dumping duties for the importers that rely on these goods. Moreover, changes in the rules for determining the extent of injury and allowing antidumping measures against non-market countries such as China has helped to further support the petitioning parties. Second, once anti-dumping duties have been established, there may be a potential political coalition across countries between between importers and exporters. However, the prohibitively high costs of litigation at the WTO make it difficult for cross-border cooperation to materialize. In this, GVCrelated interests are no different from economic actors not embedded in GVCs. Protrade forces overall face major obstacles in exerting their political influence in the domestic political arena and in filing at the WTO.

The broader implication of our study is that the political mobilization of GVCrelated interests may be most effective before an anti-dumping petition is filed and after WTO disputes have been settled. As firms become more linked through global value chains and thus become more reliant on the supply of intermediate goods, they have less incentive to petition for anti-dumping measure and thus more effective in preventing them. On the other end following dispute settlement at the WTO, GVCrelated interests can also effectively organize to ensure swift compliance. Between these two points, however, GVC-related interests, and pro-trade forces overall, face major hurdles in advancing their opposition to protectionist measures.

Moving forward, future research should consider anti-dumping measures taken by countries other than the US, which is, after all, still the world's leading economy. An important follow-up question is how far the current study's findings travel and whether a similar situation obtains in other country settings as well. In addition, the 
consideration of third parties can further push the applicability of this paper's findings. On the one hand, adding third parties would increase the value of trade at stake; on the other, it could exacerbate collective action problems for the firms and governments involved. Finally, at the time of writing, the WTO dispute settlement system is facing multiple requests for consultation with the United States as respondent. For the US as respondent on Certain Measures on Steel and Aluminum Products, complainants include international coalition: Turkey, Switzerland, Russia, Norway, Mexico, Canada, EU, India, China, and counting. These filings challenge the Trump administration's invocation of the national security exception and the legality of US' tariffs vis'a-vis the WTO's safeguard provisions. Given that the steel and aluminum tariffs comprise a good $\$ 50$ billion, the size of the growing coalition of opposing forces provides an interesting further test of the findings of this paper about the conditions under which this coalition can successfully overcome collective action problems and move toward litigation. An international coalition of state actors with the capacity for action, and a supporting coalition of domestic pro-trade forces that have significant economic stakes that outweigh the costs of litigation at the WTO, can be the way forward in successfully opposing the economic nationalism of this populist era.

\section{References}

Aw, B. Y., Chung, S., and Roberts, M. J. (1998). Productivity and the decision to export: Micro evidence from Taiwan and South Korea. Technical report, National Bureau of Economic Research.

Baccini, L., Dür, A., \& Elsig, M. (2018). Intra-industry trade, global value chains, and preferential tariff liberalization. International Studies Quarterly, 62, 329-340.

Bernard, A. B., \& Jensen, J. B. (1999). Exceptional exporter performance: Cause, effect, or both? Journal of International Economics, 47(1), 1-25.

Bernard, A. B., Eaton, J., Jensen, J. B., \& Kortum, S. (2003). Plants and productivity in international trade. American Economic Review, 93(4), 1268-1290.

Bown, C. P. (2010). China's wto entry: Antidumping, safeguards, and dispute settlement. In China's growing role in world trade (pp. 281-337). University of Chicago Press.

Bown, C. P. (2014). Global antidumping database. The world bank, june.

Brutger, R. (2014). Screening for success: The effect of firm signaling on wto case selection. In Washington, DC: Annual Meeting of the American Political Science Association.

Busch, M. L., \& Reinhardt, E. (2000). Bargaining in the shadow of the law: Early settlement in gatt/wto disputes. Fordham International LJ, 24, 158.

Busch, M. L., \& Reinhardt, E. (2003). Developing countries and general agreement on tariffs and trade/world trade organization dispute settlement. J. World Trade, 37, 719.

Curran, L., \& Eckhardt, J. (2017). Smoke screen? The globalization of production, transnational lobbying and the international political economy of plain tobacco pack- aging. Review of International Political Economy, 24(1), 87-118.

Davis, C. L., \& Bermeo, S. B. (2009). Who files? Developing country participation in gatt/wto adjudication. The Journal of Politics, 71(3), 1033-1049.

Davis, C. L., \& Shirato, Y. (2007). Firms, governments, and wto adjudication: Japan's selection of wto disputes. World Politics, 59(2), 274-313.

Eaton, J., \& Kortum, S. (2002). Technology, geography, and trade. Econometrica, 70(5), 1741-1779.

Eaton, J., Kortum, S., \& Kramarz, F. (2004). Dissecting trade: Firms, industries, and export destinations. American Economic Review, 94(2), 150-154.

Eckhardt, J., \& Poletti, A. (2016). The politics of global value chains: Import-dependent firms and EU-Asia trade agreements. Journal of European Public Policy, 23(10), 1543-1562.

Elsig, M., \& Stucki, P. (2012). Low-income developing countries and wto litigation: Why wake up the sleeping dog? Review of International Political Economy, 19(2), 292-316. 
Francois, J., Horn, H., and Kaunitz, N. (2007). Trading profiles and developing country participation in the wto dispute settlement system.

Guzman, A. T., \& Simmons, B. A. (2005). Power plays and capacity constraints: The selection of defendants in world trade organization disputes. The Journal of Legal Studies, 34(2), 557-598.

Jensen, J. B., Quinn, D. P., \& Weymouth, S. (2015). The influence of firm global supply chains and foreign currency undervaluations on us trade disputes. International Organization, 69(4), 913-947.

Johns, L., \& Pelc, K. J. (2014). Who gets to be in the room? Manipulating participation in wto disputes. International Organization, 68(3), 663-699.

Johns, L., \& Wellhausen, R. L. (2016). Under one roof: Supply chains and the protec- tion of foreign investment. American Political Science Review, 110(1), 31-51.

Kim, I. S. (2017). Political cleavages within industry: Firm-level lobbying for trade liberalization. American Political Science Review, 111(1):1-20, 1.

Kim, I. S., Milner, H. V., Bernauer, T., Osgood, I., Spilker, G., and Tingley, D. (2019). Firms and global value chains: Identifying firms' multidimensional trade. Interna-tional Studies Quarterly, pages 1-15.

Lawton, T. C., \& McGuire, S. M. (2001). Supranational governance and corporate strategy: The emerging role of the world trade organization. International Business Review, 10(2), 217-233.

Manger, M. S. (2009). Investing in protection: The politics of preferential trade agreements between north and south. Cambridge: Cambridge University Press.

Melitz, M. J. (2003). The impact of trade on intra-industry reallocations and aggregate industry productivity. Econometrica, 71(6), 1695-1725.

Osgood, I. (2018). Globalizing the supply chain: Firm and industrial support for us trade agreements. International Organization, 72(2), 455-484.

Palmeter, D. N. (2000). The wto as a legal system. Fordham International Law Jornal, 24(1 \& 2), 440-480.

Poletti, A., \& De Bièvre, D. (2014). Political mobilization, veto players, and wto litigation: explaining european union responses in trade disputes. Journal of European Public Policy, 21(8), 1181-1198.

Rosendorff, B. P. (2005). Stability and rigidity: Politics and design of the wto's dispute settlement procedure. American Political Science Review, 99(3), 389-400.

Sattler, T., \& Bernauer, T. (2011). Gravitation or discrimination? Determinants of litigation in the world trade organisation. European Journal of Political Research, 50(2), 143-167.

Sattler, T., Spilker, G., \& Bernauer, T. (2014). Does wto dispute settlement enforce or inform? British Journal of Political Science, 44(4), 877-902.

Steger, D. P., \& Hainsworth, S. M. (1998). World trade organization dispute settlement: The first three years. Journal International Econ. L., 1, 199-226.

Yildirim, A. B. (2018). Firms integration into value chains and compliance with adverse wto panel rulings. World Trade Review, 17(1), 131.

Yildirim, A. B., Chatagnier, J. T., Poletti, A., \& De Bièvre, D. (2018). The interna- tionalization of production and the politics of compliance in wto disputes. The Review of International Organizations, 13(1), 49-75.

Zangl, B. (2008). Judicialization matters! A comparison of dispute settlement under gatt and the wto. International Studies Quarterly, 52(4), 825-854. 